\title{
KARAKTERISTIK, KESESUAIAN, DAN PENGELOLAAN LAHAN TAMBAK DI KECAMATAN BULAKAMBA KABUPATEN BREBES PROVINSI JAWA TENGAH
}

\author{
Rachmansyah, Andi Indra Jaya Asaad, dan Akhmad Mustafa \\ Balai Penelitian dan Pengembangan Budidaya Air Payau \\ Jl. Makmur Dg Sitakka No. 129, Maros 90512, Sulawesi Selatan \\ E-mail:rachman222000@yahoo.com
}

(Naskah diterima: 28 Desember 2011; Disetujui publikasi: 9 Juli 2012)

\begin{abstract}
ABSTRAK
Kabupaten Brebes memiliki lahan tambak yang produktivitasnya masih tergolong relatif rendah. Oleh karena itu, dilakukan survai untuk mengetahui karakteristik lahan dalam upaya menentukan kesesuaian dan pengelolaan lahan untuk budidaya tambak dalam upaya peningkatan produktivitas tambak di Kabupaten Brebes. Faktor yang dipertimbangkan dalam mengetahui karakteristik lahan adalah: tanah, topografi, hidrologi, dan iklim. Analisis spasial dalam Sistem Informasi Geografis digunakan untuk penentuan kesesuaian lahan budidaya tambak. Hasil penelitian menunjukkan bahwa peubah kualitas air Sungai Kluwut dan pesisir Kecamatan Bulakamba kurang mendukung sebagai sumber air primer untuk kegiatan budidaya pada musim kemarau. Kualitas tanah tambak secara umum dapat mendukung usaha tambak yang dikelola secara tradisional sampai madya, di mana pada areal tertentu dijumpai adanya potensi kemasaman walaupun dalam jumlah yang rendah. Dari luas tambak yang ada di Kecamatan Bulakamba, yaitu 1.485,3 ha ternyata tidak ada tambak yang tergolong sangat sesuai (kelas S1), 145,7 ha tergolong cukup sesuai (kelas S2) dan 1.339,6 ha tergolong kurang sesuai (kelas S3). Upaya remediasi perlu dilakukan pada areal yang memiliki kandungan $\mathrm{S}_{\text {pos }}$ tanah tinggi dan perlu pula dilakukan pemupukan yang mengandung nitrogen seperti urea untuk menstabilkan rasio $\mathrm{C}: \mathrm{N}$ tanah serta penambahan pupuk kandang untuk memperbaiki struktur tanah yang didominasi oleh fraksi liat. Perlu adanya upaya input teknologi dan infrastruktur untuk aliran massa air tawar dan penentuan pola dan waktu budidaya dengan memperhatikan faktor kunci salinitas.
\end{abstract}

KATA KUNCI: karakteristik, kesesuaian, pengelolaan lahan, tambak, Kabupaten Brebes

ABSTRACT: Characteristic, suitability, and management of ponds in Bulakamba Sub-district Brebes District Central Java Provinces. By: Rachmansyah, Andi Indra Jaya Asaad, and Akhmad Mustafa

The characteristic of tambak (shrimp ponds) in Brebes District is relatively low productivity. A research has been conducted to determine the characteristics of the land in order to provide data on suitability and land management for aquaculture ponds in Brebes. The considered factors to understand the land characteristics are: soil, topography, hydrology, and climate. Spatial analysis has been applied to determine the suitability of shrimp ponds. The results showed that the water of Kluwut River and adjacent coastal area are not suitable as the primary source of 
water for aquaculture particularly in the dry season. Generally, the soil quality in Bulakamba, Brebes can support the traditional aquaculture or even in applied middle technology of aquaculture. There are several area found as potential acid soil area. The suitability of shrimp ponds in Bulakamba Sub-district are found 145.7 ha as quite suitable (S2) and 1.339,6 ha as not suitable class (S3). Soil remediation is an important strategy to be adapted particularly in area with high $S_{\text {pos. }}$. Therefore, the fertilization is also important especially urea to stabilize the C:N ratio in the soil. Dung fertilization is needed to fix the soil structure which is dominated by clay fraction. Technology and infrastructure are urgent to be developed particularly for establishing the freshwater in the shrimp ponds. Besides, the aquaculture season is important to be calculated by considering the salinity as key factor in shimp ponds Bulakamba Subdistrict.

KEYWORDS: characteristic, suitability, land management, shrimp ponds, Brebes District

\section{PENDAHULUAN}

Kabupaten Brebes termasuk dalam Kawasan Strategis Bregas, sub-wilayah pengembangan Jawa Tengah yang telah ditetapkan dalam Rencana Tata Ruang Wilayah Provinsi (RTRWP) Jawa Tengah. Kawasan tersebut terdiri atas wilayah Kota Tegal, Kabupaten Brebes, Kabupaten Tegal yang masing-masing mempunyai potensi besar untuk berkembang. Pusat pertumbuhan kawasan ini berada di Kota Tegal, dengan wilayah pendukung yang akan saling membutuhkan adalah Kabupaten Brebes dan Kabupaten Tegal.

Sungai Kluwut merupakan bagian dari DAS Kabuyan yang secara administratif meliputi Kecamatan Ketanggungan, Bulakamba, dan Larangan. Daerah hulu Sungai Kluwut ini terletak di Desa Cipelem Kecamatan Bulakamba. Fungsi utama sungai ini khususnya bagian hulu adalah sumber air pengairan pertanian bawang merah. Pada bagian hilir sungai ini terutama pada wilayah administratif Desa Grinting terdapat kawasan tambak yang pada awalnya sebagian besar dikelola secara intensif, namun saat ini dikelola secara tradisional. Komoditas yang dikembangkan saat ini adalah ikan bandeng, sebagian kecil udang vaname dan udang windu. Eksternalitas kegiatan pertanian yang intensif pada daerah hulu dan tengah Sungai Kluwut dapat berdampak negatif pada aktivitas hilir yaitu kegiatan akuabisnis tambak bandeng dan udang. Penggunaan pestisida untuk mengatasi masalah organisme pengganggu tanaman (OPT) bawang tergolong tinggi dan tidak sesuai aturan dapat menyebabkan dampak negatif terhadap manusia dan lingkungan.
Semua jenis komoditas termasuk komoditas perikanan budidaya yang berbasis lahan untuk dapat tumbuh atau hidup dan berproduksi memerlukan persyaratan-persyaratan tertentu, yang dapat berbeda satu sama lain. Dalam kaitannya dengan sumberdaya alam, dikenal istilah lahan yang merupakan suatu lingkungan fisik yang terdiri atas tanah, topografi, hidrologi, vegetasi, dan iklim di mana pada batas-batas tertentu mempengaruhi kemampuan penggunaan lahan (FAO, 1976). Oleh karena itu, perbedaan kombinasi penyusun lingkungan fisik lahan tersebut akan memberikan karakteristik lahan yang berbeda dan pada akhirnya pengelolaan lahan yang berbeda pula.

Pengelolaan Iahan yang tepat dapat meningkatkan produktivitas lahan termasuk lahan budidaya tambak dengan penggunaan masukan yang seminimal mungkin dan tidak menyebabkan terjadinya degradasi lingkungan. Setiap jenis lahan memiliki karakteristik tersendiri sehingga pengelolaan lahan tersebut juga bersifat khas terhadap penggunaan lahan tersebut.

Penelitian ini bertujuan untuk mengetahui kualitas lingkungan perairan di Sungai Kluwut (Hulu, Tengah, Hilir) dan daerah pesisir sekitar Sungai Kluwut yang merupakan sumber air primer bagi kawasan tambak Kecamatan Bulakamba serta karakteristik lahan untuk menentukan kesesuaian dan pengelolaan lahan tambak di Kecamatan Bulakamba Kabupaten Brebes. Hasil penelitian ini juga diharapkan dapat dijadikan acuan dalam penentuan Rencana Tata Ruang Wilayah Kabupaten Brebes secara khusus dan Provinsi Jawa Tengah secara umum. 


\section{BAHAN DAN METODE}

Penelitian ini telah dilaksanakan pada bulan Oktober 2009 di Daerah Aliran Sungai Kluwut, kawasan tambak dan pesisir yang secara administratif termasuk dalam Kecamatan Bulakamba, Kabupaten Brebes. Penelitian ini dikelompokkan menjadi dua bagian yaitu kelompok sungai dan kelompok tambak. Untuk kelompok sungai, pengambilan contoh meliputi daerah hulu, tengah, hilir Sungai Kluwut, daerah pesisir yang berbatasan dengan muara Kluwut serta beberapa titik pada daerah tambak di sekitar daerah aliran sungai (Gambar 1). Pada Gambar 1 dapat dilihat titik pengambilan contoh oleh kelompok sungai yang terdiri atas: area pertanian bawang merah (P1, P2, P3); perairan Sungai Kluwut (P4, P5, P7); daerah pesisir yang berbatasan dengan muara Sungai Kluwut (P8, P9, P10).

Pengukuran kualitas air dilakukan secara in situ yang meliputi pengukuran suhu, $\mathrm{pH}$, salinitas, oksigen terlarut, dan padatan terlarut total. Pengukuran peubah ini dilakukan dengan menggunakan alat YSI 650 MDS. Peubah yang diukur in situ lainnya adalah kecerahan perairan (secchi disk) dan kecepatan arus (layang-layang arus). Sementara pengukuran in situ sedimen meliputi pengukuran $\mathrm{pH}_{\mathrm{F}}$ dan potensial redoks.

Selain itu, dilakukan pengambilan contoh air dan sedimen untuk dianalisis lebih lanjut di Laboratorium Air Balai Penelitian dan Pengembangan Budidaya Air Payau (BPPBAP) Maros. Contoh air sebanyak $1 \mathrm{~L}$ dipreservasi dalam botol polyethylene dan dimasukkan ke dalam cool box yang telah diberi es batu. Hal yang sama dilakukan terhadap contoh sedimen sebanyak $\pm 800-1.000 \mathrm{~g}$ yang dimasukkan dalam plastik kedap air ukuran $2 \mathrm{~kg}$. Contoh air untuk analisis di laboratorium diambil dengan menggunakan Kmerer Water Sampler dan dipreservasi mengikuti petunjuk APHA (2005). Peubah kualitas air yang dianalisis di Laboratorium Air BPPBAP di Maros meliputi: $\mathrm{NH}_{3}, \mathrm{NO}_{3}$, $\mathrm{NO}_{2}$, dan Fe berdasarkan petunjuk Menon (1973), Parsons et al. (1989), dan APHA (2005).

Sebanyak 23 titik pengambilan sampel tanah tambak ditentukan secara acak sederhana. Contoh tanah diambil dengan menggunakan bor tanah pada 2 (dua) kedalaman tanah yaitu 0-0,2 $\mathrm{m}$ dan 0,5-0,7 m dari permukaan tanah. Seluruh titik-titik pengamatan dan pengambilan contoh ditentukan titik koordinatnya dengan menggunakan Global Positioning System (GPS). Peubah kondisi tanah yang diukur langsung di lapangan berupa kedalaman tanah sampai lapisan padas keras dengan menggunakan bor tanah yang dilengkapi dengan meteran. Peubah kualitas tanah yang diukur langsung di lapangan adalah $\mathrm{pH}_{\mathrm{F}}(\mathrm{pH}$ tanah yang diukur di lapangan) dengan $\mathrm{pH}$-meter (Ahern \& Rayment, 1998) dan $\mathrm{pH}_{\mathrm{Fox}}$ ( $\mathrm{pH}$ tanah yang diukur di lapangan setelah dioksidasi dengan hidrogen peroksida $\left(\mathrm{H}_{2} \mathrm{O}_{2}\right)$ $30 \%$ ) dengan $\mathrm{pH}$-meter (Ahern \& Rayment, 1998) serta potensial redoks dengan redoxmeter. Contoh tanah diambil pada 2 (dua) kedalaman tanah yaitu 0-0,2 m dan 0,5-0,7 m dari permukaan tanah, kemudian dimasukkan dalam kantong plastik dan selanjutnya dimasukkan dalam cool box yang diberi es, karena adanya contoh tanah yang tergolong tanah sulfat masam.

Selanjutnya contoh tanah di-oven-kan pada suhu $80^{\circ} \mathrm{C}-85^{\circ} \mathrm{C}$ selama 48 jam (Ahern $\&$ Blunden, 1998) untuk tanah sulfat masam, sedangkan contoh tanah lainnya dikeringanginkan. Setelah kering, contoh tanah dihaluskan dengan cara ditumbuk pada lumpang porselin dan diayak dengan ayakan ukuran lubang $2 \mathrm{~mm}$ dan selanjutnya dianalisis di Laboratorium Tanah Balai Penelitian dan Pengembangan Budidaya Air Payau (BPPBAP) di Maros. Kualitas tanah yang dianalisis di laboratorium meliputi $\mathrm{pH}_{\mathrm{KCl}}(\mathrm{pH}$ dari ekstrak $\mathrm{KCl}$ ) (McElnea \& Ahern, 2004a), $\mathrm{pH}_{\text {ox }}$ (McElnea \& Ahern, 2004b), $\mathrm{S}_{\mathrm{p}}$ (sulfur peroksida) (Melville, 1993; McElnea \& Ahern, 2004c), $\mathrm{S}_{\mathrm{KCl}}$ (sulfur yang diekstrak dengan $\mathrm{KCl}$ ) (Melville, 1993; McElnea \& Ahern, 2004d), $\mathrm{S}_{\text {POS }}\left(\mathrm{S}_{\mathrm{P}}-\mathrm{S}_{\text {KCI}}\right)$ (Ahern \& McElnea, 2004), TPA (Titratable Peroxide Acidity atau sebelumnya dikenal dengan Total Potential Acidity) (McElnea \& Ahern, 2004b), TAA (Titratable Actual Acidity atau sebelumnya dikenal dengan Total Actual Acidity) (McElnea \& Ahern, 2004a), TSA (Titratable Sulfidic Acidity atau sebelumnya dikenal dengan Total Sulfidic Acidity) (TPA-TAA) (McElnea \& Ahern, 2004b), pirit (Ahern et al., 1998a; 1998b), karbon organik dengan metode Walkley dan Black (Sulaeman et al., 2005), N-total dengan metode Kjedhal (Sulaeman et al., 2005), $\mathrm{PO}_{4}$ dengan metode Bray 1 atau Olsen (Sulaeman et al., 2005), Fe dengan spektrofotometer (Menon, 1973), Al dengan spektrofotometer (Menon, 1973), dan tekstur dengan metode hidrometer (Abdurachman et al., 2006). 
Data sekunder dikumpulkan melalui penelusuran berbagai laporan, pustaka, dan hasil penelitian dari berbagai instansi terkait. Peta yang dikumpulkan antara lain peta Rupabumi Indonesia skala 1:50.000 dan peta Administrasi Kabupaten Brebes, khususnya Kecamatan Bulakamba.

Statistik deskriptif digunakan untuk dapat menggambarkan data yang ada secara umum. Peta Penutup/Penggunaan Lahan yang digunakan berasal dari hasil klasifikasi Citra Landsat dengan Program Er Mapper 7.1 yang diintegrasikan dengan peta dasar dari peta Rupabumi Indonesia.

Informasi spasial lain yang diperoleh dari data primer dan sekunder juga diintegrasikan dengan peta Penutup/Penggunaan Lahan. Data primer, sekunder, dan peta Penutup/ Penggunaan Lahan yang sudah dikumpulkan, selanjutnya dilakukan pengolahan data dengan menggunakan analisis spasial dalam Sistem Informasi Geografis (SIG) (Purwadhi,
1999). Pada proses analisis menggunakan program ArcView 3.3 dengan cara memasukkan setiap peubah data untuk menghasilkan peta tematik bagi setiap peubah data dan selanjutnya dilakukan proses tumpang tindih. Kriteria yang digunakan dalam penentuan kesesuaian lahan untuk budidaya tambak mengacu pada kriteria yang ada (Mustafa et al., 2007a).

Asumsi yang diterapkan dalam evaluasi kesesuaian lahan tambak disesuaikan pada pengelolaan yang rendah atau sederhana sampai sedang. Infrastruktur, aksesibilitas, dan pemasaran hasil produksi tidak dipertimbangkan dalam evaluasi kesesuaian lahan ini. Hasil proses penilaian kesesuaian lahan ditampilkan dalam bentuk sistem klasifikasi kesesuaian lahan aktual sampai pada kategori Kelas. Pengelolaan lahan yang direkomendasikan didasarkan pada karakteristik lahan dan disesuaikan dengan tingkat teknologi dan komoditas yang diaplikasikan di tambak.

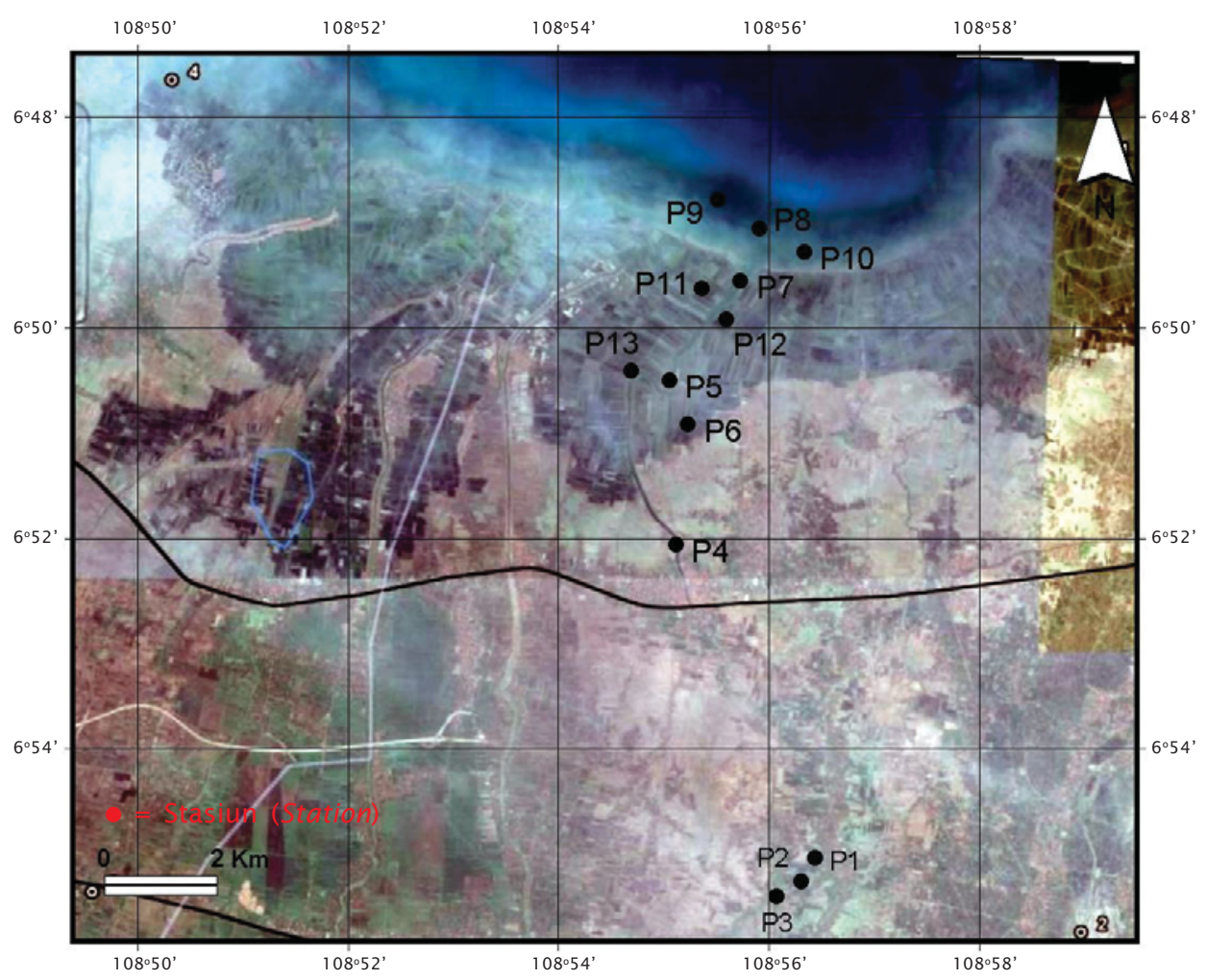

Gambar 1. Peta lokasi penelitian di Kabupaten Brebes (Sumber: Google Earth dimodifikasi)

Figure 1. Map of research location in Brebes District (Source: Google Earth modified) 


\section{HASIL DAN BAHASAN}

\section{Kualitas Air Sungai, Pesisir, dan Tambak}

Pada stasiun/titik pengamatan di daerah pertanian bawang merah (P1, P2, P3) (Gambar 1) yang berada di sekitar daerah hulu Sungai Kluwut Desa Cibelem, contoh air di parit pertanian bawang dikoleksi untuk analisis lanjutan pestisida. Sedangkan pada perairan sungai (P4, P5, P7 pada Gambar 1) dan daerah pesisir di sekitar muara Sungai Kluwut (P8, P9, P10 pada Gambar 1) nilai kualitas air dan sedimen dapat dilihat pada Tabel 1. Parameter tersebut menunjukkan nilai kualitas sumber air primer bagi kawasan tambak di Kecamatan Bulakamba.

Pada Tabel 1, nilai kualitas air Sungai Kluwut menggambarkan bahwa perairan Sungai Kluwut kurang mendukung sebagai sumber air untuk kegiatan budidaya tambak. Sebagaimana telah disebutkan bahwa sungai ini merupakan sumber air untuk tambak-tambak di daerah hilir. Nilai kandungan oksigen terlarut saja sudah menunjukkan angka kritis $3,23 \pm 1,1 \mathrm{mg} / \mathrm{L}$ di mana kandungan oksigen terlarut direferensikan pada nilai $83 \mathrm{mg} / \mathrm{L}$ (Haliman et al., 2006). Kedalaman perairan sungai berkisar antara 1,1-1,85 m. Dangkalnya sungai ini disebabkan karena sedimentasi yang telah berlangsung sejak lama, bahkan mengganggu aktivitas lalu lintas kapal penangkapan. Hal ini berpengaruh terhadap kecerahan perairan di mana kisaran menunjukkan nilai yang rendah yaitu 0,2-0,4 m.

Peubah kualitas air yang paling ekstrem adalah salinitas yang berkisar antara 41,42 44,87 ppt $(43,46 \pm 1.8$ ppt). Nilai ini sudah di luar konsentrasi normal untuk perairan laut sekalipun. Nilai salinitas pada daerah hulu masih menunjukkan nilai alami untuk perairan tawar dengan salinitas 0,25 ppt. Namun pada bagian tengah hingga hilir Sungai Kluwut, nilai salinitas sangat tinggi. Hal ini disebabkan karena musim kemarau berkepanjangan dan kurangnya pasokan air tawar dari hulu serta aliran air yang cenderung stagnan di mana kecepatan arus hanya $0,087 \pm 0.086 \mathrm{~m} /$ detik. Tingginya nilai salinitas ini memberikan gambaran bahwa kawasan tambak di daerah hilir kurang optimal untuk pengembangan budidaya perikanan. Menurut Haliman et al. (2006), untuk budidaya udang vaname salinitas yang direferensikan berkisar antara 15-30 ppt.
Kandungan nitrat pada perairan alami hampir tidak pernah lebih dari $0,1 \mathrm{mg} / \mathrm{L}$ (Effendi, 2003). Perairan oligotrofik memiliki kandungan nitrat antara 0-1 mg/L. Berdasarkan pengelompokkan tersebut, maka perairan Sungai Kluwut tergolong kategori oligotrofik. Nilai kisaran nitrat masih mendukung kehidupan biota budidaya karena nilai yang disyaratkan adalah kurang dari $0,5 \mathrm{mg} / \mathrm{L}$ (BRPBAP, 2007). Peubah nitrit memiliki kisaran 0,867 $\pm 1,44 \mathrm{mg} / \mathrm{L}$. Menurut Moore (1991), bahwa kandungan nitrit yang lebih dari 0,05 $\mathrm{mg} / \mathrm{L}$ dapat bersifat toksik bagi organisme perairan yang sangat sensitif.

Nilai amonia masih memiliki kecenderungan yang layak $(0,161 \pm 0,18 \mathrm{mg} / \mathrm{L})$ untuk kegiatan budidaya, walaupun pada beberapa titik pengamatan nilai amonia melebihi 0,15 $\mathrm{mg} / \mathrm{L}$. Sebagaimana yang dikemukakan oleh Lazur (tanpa tahun) bahwa nilai amonia yang disyaratkan untuk aktivitas budidaya di kolam/ tambak adalah kurang dari 0,15 mg/L. Nilai amonia yang sudah berbahaya adalah terdapat pada stasiun P4 yaitu di perairan sungai sekitar TPI Kluwut. Nilai amonia yaitu $0,368 \mathrm{mg} / \mathrm{L}$ kondisi ini dapat mengakibatkan kematian biota karena menurut Sawyer \& McCarty (1978), bahwa jika kandungan amonia bebas lebih dari $0,2 \mathrm{mg} / \mathrm{L}$ maka perairan tersebut bersifat toksik bagi beberapa jenis ikan.

Rata-rata kandungan fosfat menunjukkan nilai $0,467 \pm 0,684 \mathrm{mg} / \mathrm{L}$. Pengelompokkan kesuburan perairan berdasarkan konsentrasi fosfat yaitu oligotrofik: 0,003-0,01 mg/L; mesotrofik: 0,01 1-0,03 mg/L; eutrofik: 0,031$0,1 \mathrm{mg} / \mathrm{L}$ (Vollenweider dalam Wetzel, 1975 dalam Effendi, 2003). Hal ini menunjukkan bahwa perairan Sungai Kluwut termasuk perairan eutrofik tinggi. Pengkayaan unsur hara perairan dapat menyebabkan kejadian blooming alga yang dapat menurunkan kandungan oksigen terlarut karena terjadi persaingan oksigen. Nilai fosfat menunjukkan kisaran yang cukup tinggi yaitu 0,044-50 $\mathrm{mg} / \mathrm{L}$. Stasiun P7 yang terletak di dekat muara memiliki konsentrasi yang sangat tinggi yaitu $50 \mathrm{mg} / \mathrm{L}$. Konsentrasi besi yang melebihi $1 \mathrm{mg} / \mathrm{L}$ dapat membahayakan kehidupan organisme akuatik (Moore, 1991).

Nilai kualitas air pada perairan pesisir juga tidak jauh berbeda dengan kualitas perairan Sungai Kluwut. Nilai salinitas menunjukkan nilai yang termasuk normal untuk air laut. Salinitas yang lebih rendah pada perairan 
Tabel 1. Kualitas air perairan dan sedimen Sungai Kluwut $(n=3)$ dan kualitas air dan sedimen daerah pesisir sekitar muara Sungai Kluwut Kabupaten Brebes Provinsi Jawa Tengah $(n=3)$

Table 1. Water and sediment quality of Kluwut River $(n=3)$ and coastal of adjacent Kluwut estuary Brebes District Central Java Province $(n=3)$

\begin{tabular}{|c|c|c|c|c|}
\hline \multirow[t]{2}{*}{$\begin{array}{l}\text { Peubah } \\
\text { Variables }\end{array}$} & \multicolumn{2}{|c|}{$\begin{array}{c}\text { Perairan Sungai Kluw ut } \\
\text { Kluwut River }\end{array}$} & \multicolumn{2}{|c|}{$\begin{array}{c}\text { Daerah pesisir } \\
\text { sekitar muara Sungai Kluw ut } \\
\text { Coastal area of } \\
\text { adjacent Kluwut Est uary }\end{array}$} \\
\hline & $\begin{array}{l}\text { Kisaran } \\
\text { Range }\end{array}$ & $\begin{array}{l}\text { Rataan } \\
\text { Average }\end{array}$ & $\begin{array}{l}\text { Kisaran } \\
\text { Range }\end{array}$ & $\begin{array}{l}\text { Rataan } \\
\text { Average }\end{array}$ \\
\hline $\begin{array}{l}\text { Oksigen te rlarut } \\
\text { Dissolved oxygen }(\mathrm{mg} / \mathrm{L})\end{array}$ & $2.56-4.46$ & $3.23 \pm 1.1$ & $5.48-5.9$ & $5.66 \pm 0.22$ \\
\hline Suhu (Temperature) $\left({ }^{\circ} \mathrm{C}\right)$ & $30.1-34.12$ & $32.6 \pm 2.2$ & $30.23-30.27$ & $30.25 \pm 0.021$ \\
\hline Kedalaman (Depth) (m) & $1.1-1.85$ & - & $1.1-1.2$ & - \\
\hline Salinitas (Salinity) (ppt) & $41.42-44.87$ & $43.46 \pm 1.8$ & $34.8-34.9$ & $34.9 \pm 0.04$ \\
\hline $\mathrm{pH}$ & $8.01-8.22$ & $8.09 \pm 0.1$ & $8.1-8.11$ & $8.107 \pm 0.006$ \\
\hline $\begin{array}{l}\text { Kecerahan } \\
\text { Water Clarity (m) }\end{array}$ & $0.25-0.4$ & $0.33 \pm 0.08$ & $0.15-0.25$ & $0.207 \pm 0.05$ \\
\hline $\begin{array}{l}\text { Bahan organik total } \\
\text { Total organic matter } \\
(\mathrm{mg} / \mathrm{L})\end{array}$ & $30.24-39.68$ & $34.15 \pm 4.9$ & $30.89-38.38$ & $35.45 \pm 4$ \\
\hline Nitrat (Nitrate) (mg/L) & $0.015-0.97$ & $0.361 \pm 0.53$ & $0.017-0.871$ & $0.304 \pm 0.5$ \\
\hline Nitrit (Nitrite) (mg/L) & $0.016-2.531$ & $0.867 \pm 1.44$ & $0.023-0.085$ & $0.044 \pm 0.035$ \\
\hline Amonia (Ammonia) (mg/L) & $0.051-0.368$ & $0.161 \pm 0.18$ & $0.017-0.05$ & $0.039 \pm 0.018$ \\
\hline Fosfat (Phosphate) (mg/L) & $0.004-1.253$ & $0.467 \pm 0.684$ & $0.058-0.123$ & $0.085 \pm 0.034$ \\
\hline Besi $(F e)(m g / L)$ & $0.044-0.50$ & & $0.021-0.028$ & $0.025 \pm 0.004$ \\
\hline $\begin{array}{l}\text { Kecepatan arus ( } \mathrm{m} / \text { detik) } \\
\text { Water current ( } \mathrm{m} / \mathrm{sec} \text { end) }\end{array}$ & $0.026-0.15$ & $0.087 \pm 0.086$ & $0.052-0.081$ & $0.07 \pm 0.016$ \\
\hline $\begin{array}{l}\text { Lebar sungai } \\
\text { River width (m) }\end{array}$ & $27-44$ & - & - & - \\
\hline $\begin{array}{l}\mathrm{pH}_{\mathrm{F}} \text { sedimen } \\
\text { Sediment } p \mathrm{H}_{f}\end{array}$ & $6.4-6.88$ & $6.65 \pm 0.24$ & $7.13-7.26$ & $7.19 \pm 0.066$ \\
\hline $\begin{array}{l}\text { Potensial redoks sedimen } \\
\text { Sediment redox potential } \\
(\mathrm{mV})\end{array}$ & $-236.4-(-47.3)$ & $-152.9 \pm 96.5$ & $-200.5-(-108.7)$ & $-149.7 \pm 46.67$ \\
\hline
\end{tabular}

pesisir dibandingkan dengan perairan sungai dikarenakan adanya pergerakan air yang dinamis pada pesisir, sedangkan pada perairan sungai, hampir tidak ada pergerakan air yang signifikan.

Pada Tabel 2 dapat dilihat kisaran dan ratarata peubah kualitas air tambak tradisional di Kecamatan Bulakamba. Secara umum nilai kualitas fisika dan kimia perairan tambak menunjukkan nilai yang tidak optimum untuk kegiatan budidaya.

Salinitas air tambak berkisar dari 35-71 ppt dengan rata-rata 58,63 ppt. Udang windu, udang vaname, bandeng, dan rumput laut merupakan organisme eurihalin, namun karena dibudidayakan untuk tujuan komersial, kisaran salinitas yang optimum perlu dipertahankan. Udang windu mampu menyesuaikan diri 
Tabel 2. Kualitas air tambak di Kecamatan Bulakamba Kabupaten Brebes Provinsi Jawa Tengah $(n=18)$

Table 2. Water quality of ponds in Bulakamba Sub-district Brebes District Central Java Province $(n=18)$

\begin{tabular}{|c|c|c|}
\hline $\begin{array}{l}\text { Peubah } \\
\text { Variables }\end{array}$ & $\begin{array}{l}\text { Kisaran } \\
\text { Range }\end{array}$ & $\begin{array}{l}\text { Rataan } \\
\text { Average }\end{array}$ \\
\hline $\begin{array}{l}\text { Oksigen terlarut } \\
\text { Dissolved oxygen (mg/L) }\end{array}$ & $2.34-7.62$ & $5.33 \pm 1.42$ \\
\hline Suhu (Temperature) $\left({ }^{\circ} \mathrm{C}\right)$ & $29.81-36.25$ & $33.41 \pm 2.23$ \\
\hline Salinitas (Salinity) (ppt) & $35.10-70.74$ & $58.63 \pm 13.53$ \\
\hline $\mathrm{pH}$ & $6.24-8.90$ & $7.25 \pm 0.933$ \\
\hline $\begin{array}{l}\text { Bahan organik total } \\
\text { Total organic matter }(\mathrm{mg} / \mathrm{L})\end{array}$ & $26.99-56.28$ & $38.22 \pm 7.8$ \\
\hline Nitrat (Nitrate) (mg/L) & $0.02-0.30$ & $0.11 \pm 0.08$ \\
\hline Nitrit (Nitrite) $(\mathrm{mg} / \mathrm{L})$ & $0.01-0.79$ & $0.07 \pm 0.19$ \\
\hline Amonia (Ammonia) (mg/L) & $0.02-0.64$ & $0.22 \pm 0.21$ \\
\hline Fosfat (Phosphate) (mg/L) & $0.04-1.89$ & $0.45 \pm 0.53$ \\
\hline Besi $(F e)(\mathrm{mg} / \mathrm{L})$ & $0.03-0.84$ & $0.14 \pm 0.19$ \\
\hline
\end{tabular}

terhadap salinitas 3-45 ppt (Tseng, 1987 dalam Poernomo, 1988), namun untuk pertumbuhan optimum diperlukan salinitas 15 25 ppt (Poernomo, 1988). Udang vaname umumnya tumbuh optimum pada salinitas 1520 ppt (Bray et al., 1994). Salinitas optimum untuk rumput laut adalah 15 sampai 25 ppt (Lin, 1974; Anonymous, 1991). Dari rata-rata salinitas di pertambakan Kecamatan Bulakamba, tergolong berada pada salinitas yang agak tinggi bagi berbagai komoditas air payau. Hal ini sebagai akibat dari pengukuran yang dilakukan pada saat musim kemarau yang dapat menyebabkan tingginya laju penguapan yang dapat mempertinggi salinitas. Selain itu, juga sebagai akibat tidak adanya sumber air tawar yang memadai untuk dapat menurunkan salinitas air pada musim kemarau.

Oksigen terlarut air tambak di Kecamatan Bulakamba berkisar 2,34 sampai 7,62 mg/L. Dalam hal ini, oksigen terlarut air tambak di Kecamatan Bulakamba tergolong sesuai untuk budidaya tambak. Oleh karena budidaya yang diaplikasikan oleh pembudidaya tambak di Kecamatan Bulakamba tergolong teknologi tradisional, sehingga masalah kandungan oksigen terlarut yang rendah belum menjadi masalah. Rata-rata kandungan oksigen terlarut tambak di Kecamatan Bulakamba adalah 5,33 $\mathrm{mg} / \mathrm{L}$. Kebutuhan minimum udang windu akan oksigen terlarut adalah 2 mg/L (ASEAN, 1978).
Pada konsentrasi oksigen terlarut antara 1,5 dan 3,5 mg/L dapat menyebabkan pertumbuhan serta konsumsi pakan dan efisiensi pakan pada udang windu menjadi rendah (Tsai, 1989). Batas oksigen terlarut untuk udang windu adalah 3-10 mg/L dan optimum 4-7 $\mathrm{mg} / \mathrm{L}$ (Poernomo, 1989). Dengan konsentrasi oksigen terlarut 1-5 mg/L dalam waktu yang sangat lama menyebabkan pertumbuhan udang windu menjadi lambat, konsentrasi oksigen terlarut $5 \mathrm{mg} / \mathrm{L}$ sampai jenuh adalah kondisi terbaik untuk pertumbuhan udang windu (Boyd, 1989).

Suhu air di pertambakan Kecamatan Bulakamba berkisar antara $29,81^{\circ} \mathrm{C}-36,25^{\circ} \mathrm{C}$ dengan rata-rata $33,41{ }^{\circ} \mathrm{C}$ (Tabel 2). Suhu air yang tinggi terukur pada tambak yang airnya sangat dangkal (kurang dari $10 \mathrm{~cm}$ ). Suhu air yang layak untuk budidaya udang windu berkisar antara $26^{\circ} \mathrm{C}$ dan $32^{\circ} \mathrm{C}$ (Poernomo, 1988) serta antara $13^{\circ} \mathrm{C}$ dan $33^{\circ} \mathrm{C}$ (Poxton, 2003) dan optimumnya antara $29^{\circ} \mathrm{C}$ dan $30^{\circ} \mathrm{C}$ (Poernomo, 1988). Suhu air $25^{\circ} \mathrm{C}-30^{\circ} \mathrm{C}$ adalah suhu yang baik untuk budidaya udang windu (Chen, 1972) dan untuk rumput laut (HurtadoPonce \& Umezaki, 1987). Suhu optimum untuk pertumbuhan udang vaname adalah $28^{\circ} \mathrm{C}-30^{\circ} \mathrm{C}$ (Ponce-Palatox et al., 1997).

Batas toleransi organisme akuatik terhadap $\mathrm{pH}$ bervariasi dan dipengaruhi oleh banyak 
faktor, antara lain: suhu oksigen terlarut, alkalinitas dan adanya anion dan kation, serta jenis dan stadium organisme. Kisaran $\mathrm{pH}$ yang baik untuk udang windu adalah 7,5-8,7 dengan optimum 8,0-8,5 (Poernomo, 1988; 1989). Menurut Swingle (1968), pada umumnya $\mathrm{pH}$ air yang baik bagi organisme akuatik adalah 6,5-9,0; pada pH 9,5-11,0; dan 4,0-6,0 mengakibatkan produksi rendah dan jika lebih rendah dari 4,0 atau lebih tinggi 11,0 akan meracuni ikan. Dari Tabel 4 menunjukkan bahwa $\mathrm{pH}$ air tambak di Kecamatan Bulakamba tergolong sesuai untuk budidaya perikanan air payau. Hal ini didukung dengan tanah yang tergolong tanah Aluvial non-sulfat masam sehingga $\mathrm{pH}$ air tergolong netral.

Kandungan nitrat berkisar antara 0,02-0,30 $\mathrm{mg} / \mathrm{L}$ dengan rata-rata $0,11 \mathrm{mg} / \mathrm{L}$. Konsentrasi $\mathrm{NO}_{3}$ yang lebih dari $0,2 \mathrm{mg} / \mathrm{L}$ dapat mengakibatkan terjadinya eutrofikasi perairan yang selanjutnya menstimulir pertumbuhan alga dan tumbuhan air secara pesat.

Kandungan $\mathrm{NO}_{2}$ di kawasan pertambakan Kecamatan Bulakamba berkisar antara 0,01$0,79 \mathrm{mg} / \mathrm{L}$ dengan rata-rata $0,07 \mathrm{mg} / \mathrm{L}$. Konsentrasi $\mathrm{NO}_{2}$ pada perairan relatif kecil karena segera dioksidasi menjadi nitrat. Perairan alami mengandung $\mathrm{NO}_{2}$ sekitar 0,001 $\mathrm{mg} / \mathrm{L}$ dan sebaliknya tidak melebihi 0,06 $\mathrm{mg} / \mathrm{L}$ (Canadian Council of Resource and Environment Ministers, 1987). Di perairan, konsentrasi $\mathrm{NO}_{2}$ jarang melebihi $1 \mathrm{mg} / \mathrm{L}$ (Sawyer \& McCarty, 1978). Konsentrasi $\mathrm{NO}_{2}$ yang lebih dari $0,05 \mathrm{mg} / \mathrm{L}$ dapat bersifat toksik bagi organisme akuatik yang sangat sensitif (Moore, 1991). Oleh karena itu, kandungan $\mathrm{NO}_{2}$ air tambak tergolong dapat berdampak negatif terhadap organisme yang dibudidayakan di tambak Kecamatan Bulakamba.

Amonia dapat berada dalam bentuk molekul $\left(\mathrm{NH}_{3}\right)$ atau bentuk ion $\mathrm{NH}_{4}$, di mana $\mathrm{NH}_{3}$ lebih beracun daripada $\mathrm{NH}_{4}$ (Poernomo, 1988). $\mathrm{NH}_{3}$ dapat menembus bagian membran sel lebih cepat daripada $\mathrm{NH}_{4}$. Di tambak Kecamatan Bulakamba, kandungan amonia berkisar antara $0,02-0,64 \mathrm{mg} / \mathrm{L}$ dengan rata-rata $0,22 \mathrm{mg} / \mathrm{L}$ (Tabel 2). Konsentrasi $\mathrm{NH}_{3}$ 0,05-0,20 mg/L sudah menghambat pertumbuhan organisme akuatik pada umumnya. Apabila konsentrasi $\mathrm{NH}_{3}$ lebih dari 0,2 mg/L, perairan bersifat toksik bagi beberapa jenis ikan (Sawyer \& McCarty, 1978). Liu (1989) dan Chanratchakool et al. (1995) menyatakan bahwa kandungan amonia yang diperkenankan untuk budidaya udang windu adalah kurang dari $0,1 \mathrm{mg} / \mathrm{L}$. Dalam hal ini, ada beberapa tambak yang memiliki kandungan air yang tergolong dapat mengganggu pertumbuhan organisme yang dibudidayakan di tambak Kecamatan Bulakamba.

Konsentrasi fosfat pada perairan alami berkisar antara 0,005-0,020 mg/L; sedangkan pada air tanah bisanya berkisar $0,02 \mathrm{mg} / \mathrm{L}$ (UNESCO/WHO/UNEP, 1992). Konsentrasi $\mathrm{PO}_{4}$ jarang melebihi 0,1 mg/L; meskipun pada perairan eutrof. Konsentrasi $\mathrm{PO}_{4}$ pada perairan alami jarang melebihi $1 \mathrm{mg} / \mathrm{L}$ (Boyd, 1989). Berdasarkan konsentrasi fosfat, perairan diklasifikasikan dengan tingkat kesuburan tinggi, yang memiliki konsentrasi fosfat 0,051$0,10 \mathrm{mg} / \mathrm{L}$ (Yoshimura, 1966 dalam Liaw, 1969). Berdasarkan kriteria tersebut, maka tambak di Kecamatan Bulakamba tergolong memiliki tingkat kesuburan tinggi.

Kandungan Fe air tambak Kecamatan Bulakamba berkisar antara 0,03-0,84 mg/L dengan rata-rata $0,14 \mathrm{mg} / \mathrm{L}$ (Tabel 2). Kandungan $\mathrm{Fe}$ air ini tergolong rendah dan mendukung usaha budidaya perikanan. Kandungan $\mathrm{Fe}$ yang direkomendasikan oleh ANZECC (2000) adalah kurang dari 1,0 mg/L. Peuranen et al. (1994 dalam Ritvo et al., 2004) menyatakan bahwa kandungan Fe 0,8-1,7 $\mathrm{mg} / \mathrm{L}$ dapat merusak insang ikan salmon cokelat (Salmo trutta).

\section{Kualitas Tanah Tambak}

Pada Tabel 3 dapat dilihat nilai kualitas tanah tambak pada kedalaman berbeda, yaitu: 0-0,2 m dan 0,5-0,7 m. Tidak ada perbedaan mendasar dari nilai peubah in situ kualitas tanah yang diamati yaitu $\mathrm{pH}_{\mathrm{F}}$, potensial redoks, $\mathrm{pH}_{\text {Fox }}$, dan konduktivitas. Telah disebutkan sebelumnya bahwa tanah di Kabupaten Brebes pada umumnya adalah Aluvial non-sulfat masam yang menunjukkan potensi kemasaman yang tidak tinggi yang dapat dilihat pada selisih antara $\mathrm{pH}_{\mathrm{F}}$ dan $\mathrm{pH}_{\text {Fox }}$. Pengambilan contoh tanah tambak yang dilakukan pada tambak yang sedang tergenang atau terisi air karena digunakan untuk budidaya menunjukkan nilai potensial redoks yang bernilai negatif atau menunjukkan bahwa tanah tambak dalam kondisi tereduksi.

$\mathrm{pH}_{\mathrm{F}}$ adalah $\mathrm{pH}$ tanah yang diukur langsung di lapangan dalam kondisi tanah basah atau segar. $\mathrm{pH}_{\mathrm{F}}$ dapat digunakan untuk indikator secara cepat keberadaan dan kepelikan tanah 
Tabel 3. Kualitas tanah tambak kedalaman 0-0,2 $\mathrm{m}$ dan 0,5-0,7 m di Kecamatan Bulakamba Kabupaten Brebes Provinsi Jawa Tengah ( $\mathrm{n}=23)$

Table 3. Soil ponds quality (depth 0-0.2 $\mathrm{m}$ and 0.5-0.7 $\mathrm{m}$ ) in Bulakamba Sub-district Brebes District Central Java Province $(n=23)$

\begin{tabular}{|c|c|c|c|c|}
\hline \multirow{3}{*}{$\begin{array}{l}\text { Peubah } \\
\text { Variables }\end{array}$} & \multicolumn{4}{|c|}{ Kedalaman (Dept $h$ ) (m) } \\
\hline & \multicolumn{2}{|r|}{$0-0.2$} & \multicolumn{2}{|r|}{$0.5-0.7$} \\
\hline & $\begin{array}{l}\text { Kisaran } \\
\text { Range }\end{array}$ & $\begin{array}{l}\text { Rataan } \\
\text { Average }\end{array}$ & $\begin{array}{l}\text { Kisaran } \\
\text { Range }\end{array}$ & $\begin{array}{l}\text { Rataan } \\
\text { Average }\end{array}$ \\
\hline $\begin{array}{l}\text { Potensial redoks } \\
\text { Redox potential (mV) }\end{array}$ & $-218-(-4)$ & $-117.7 \pm 56.40$ & $-263-25$ & $-119.52 \pm 67.5$ \\
\hline $\begin{array}{l}\text { Konduktivitas } \\
\text { Conductivity (mS) }\end{array}$ & 2.0-113.2 & $62.90 \pm 32.22$ & $3.6-64.1$ & $42.44 \pm 20.04$ \\
\hline $\mathrm{pH}_{\mathrm{F}}$ & $5.13-7.38$ & $6.675 \pm 0.5895$ & $5.62-7.48$ & $6.667 \pm 0.54$ \\
\hline $\mathrm{pH}_{\mathrm{FOx}}$ & $4.09-7.31$ & $6.177 \pm 0.8957$ & $1.22-6.95$ & $5.654 \pm 1.38$ \\
\hline $\mathrm{pH}_{\mathrm{F}}-\mathrm{pH}_{\mathrm{FOX}}$ & $0-1.98$ & $0.560 \pm 0.5757$ & $0-5.55$ & $1.026 \pm 1.25$ \\
\hline $\mathrm{pH}_{\mathrm{KCl}}$ & $6.60-8.18$ & $7.343 \pm 0.4218$ & $6.58-7.93$ & $7.357 \pm 0.43$ \\
\hline $\mathrm{pH}_{\mathrm{ox}}$ & $2.08-7.33$ & $4.856 \pm 1.89$ & $1.44-7.52$ & $5.440 \pm 1.66$ \\
\hline TPA ( mol H+/ton) & $0.00-471.00$ & $107.761 \pm 164.03$ & $0-627.00$ & $69.043 \pm 174.71$ \\
\hline TAA (mol H+/ton) & $0.00-0.00$ & 0.000 & $0-0$ & 0 \\
\hline TSA (mol H+/ton) & $0.00-471.00$ & $107.761 \pm 164.03$ & $0.00-627.00$ & $69.043 \pm 174.71$ \\
\hline $\begin{array}{l}\text { Bahan organik } \\
\text { Organic matter (\%) }\end{array}$ & $0.60-3.20$ & $1.796 \pm 0.66$ & $0.45-10.60$ & $1.972 \pm 1.95$ \\
\hline Pirit (Pyrite) (\%) & $0.00-2.10$ & $0.481 \pm 0.73$ & $0.00-2.80$ & $0.308 \pm 0.78$ \\
\hline $\operatorname{Besi}(\mathrm{Fe})(\mathrm{mg} / \mathrm{L})$ & $9.50-4,884.00$ & $1,393.261 \pm 1,975.70$ & $4.50-4,904.50$ & $1,438.043 \pm 2,057.90$ \\
\hline $\mathrm{Al}(\mathrm{mg} / \mathrm{L})$ & $<0.001-991.00$ & $437.533 \pm 347.94$ & $<0.001-668.50$ & $220.144 \pm 211.95$ \\
\hline $\mathrm{PO}_{4}(\mathrm{mg} / \mathrm{L})$ & $12.1-160.06$ & $60.735 \pm 40.86$ & $12.02-139.24$ & $66.205 \pm 32.42$ \\
\hline $\begin{array}{l}\text { N-total } \\
\text { Total-N (\%) }\end{array}$ & $0.01-0.05$ & $0.019 \pm 0.0077$ & $0.01-0.04$ & $0.015 \pm 0.0060$ \\
\hline $\begin{array}{l}\text { Rasio C:N } \\
\text { C:N ratio }\end{array}$ & $21.25-113.51$ & $58.693 \pm 22.39$ & $21.25-113.51$ & $58.693 \pm 22.39$ \\
\hline
\end{tabular}

sulfat masam aktual. Tanah tambak di Kecamatan Bulakamba memiliki $\mathrm{pH}_{\mathrm{F}}$ rata-rata lebih besar 6,5 ; baik pada kedalaman 0-0,2 maupun $0,5-0,7 \mathrm{~m}$. Suatu hal yang wajar bagi tanah yang tergolong tanah aluvial non-sulfat masam. Berbeda dengan hasil pengukuran $\mathrm{pH}_{\mathrm{F}}$ adalah hasil pengukuran $\mathrm{pH}_{\mathrm{FOX}}$ yaitu $\mathrm{pH}$ yang diukur di lapangan setelah tanah diberikan hidrogen peroksida $\left(\mathrm{H}_{2} \mathrm{O}_{2}\right) 30 \%$. Pemberian $\mathrm{H}_{2} \mathrm{O}_{2} 30 \%$ dalam pengukuran $\mathrm{pH}_{\mathrm{FOX}}$ dimaksudkan agar potensi kemasaman yang ada dalam tanah dapat teroksidasi semuanya secara paksa. Sebagai akibatnya $\mathrm{pH}_{\mathrm{FOx}}$ yang terukur menjadi lebih rendah daripada hasil pengukuran $\mathrm{pH}_{\mathrm{F}}$ pada semua kedalaman tanah.
Salinitas dan alkalinitas yang tinggi tidak dapat menetralisir potensial kemasaman sehingga $\mathrm{pH}_{\mathrm{FOX}}$ tetap menjadi rendah. $\mathrm{pH}_{\mathrm{FOX}}$ yang terukur di tanah tambak Kecamatan Bulakamba adalah rata-rata 6,177 pada kedalaman tanah 0-0,2 $\mathrm{m}$ dan lebih tinggi daripada kedalaman 0,5-0,7 m (Tabel 3). Lebih tingginya $\mathrm{pH}_{\mathrm{FOx}}$ pada kedalaman 0-0,2 m diduga sebagai akibat pencucian tanah secara alami yang lebih tinggi frekuensinya pada kedalaman 0-0,2 m yang menyebabkan potensi kemasaman dapat berkurang. Nilai $\mathrm{pH}_{\mathrm{Fox}}$ ini secara umum jauh lebih tinggi jika dibandingkan dengan nilai $\mathrm{pH}_{\mathrm{FOX}}$ pada tanah tambak yang tergolong tanah sulfat masam. 
Pada tanah sulfat masam yang didominasi oleh tanaman bakau (Rhizopora apiculata) di Kabupaten Mamuju Provinsi Sulawesi Barat memiliki $\mathrm{pH}_{\mathrm{FOx}}$ 0,64 $\pm 0,132$ (Mustafa et al., 2010).

Sebagai sumber kemasaman yang penting pada tanah sulfat masam, maka sulfur yang diukur dalam bentuk $S_{\text {POS }}$ tanah telah digunakan oleh Ahern et al. (1998b) untuk menentukan kebutuhan kapur bagi tanah sulfat masam. Walaupun telah disebutkan sebelumnya bahwa secara umum, tanah tambak di Kecamatan Bulakamba tergolong tanah Aluvial non-sulfat masam, akan tetapi dijumpai tanah pada areal tertentu yang mengandung $S_{\text {POS }}$ yang tinggi.

Kandungan bahan organik tanah tambak tergolong relatif rendah tanah terutama jika tambak dikelola secara tradisional sampai madya yang masih membutuhkan pakan alami sebagai sumber makanan bagi organisme yang dibudidayakan. Walaupun kandungan bahan organik tanah tergolong relatif rendah, akan tetapi kandungan nitrogen tanah yang sangat rendah menyebabkan rasio $\mathrm{C}: \mathrm{N}$ tanah menjadi sangat tinggi yaitu dapat mencapai 114:1. Rasio C:N yang ideal untuk tambak adalah 8:1 sampai 12:1 (Boyd, 2008). Pada tanah dengan rasio $\mathrm{C}: \mathrm{N}$ tinggi, maka terjadi immobilisasi $\mathrm{N}$ oleh mikrobiologi untuk memenuhi kebutuhan metabolismenya.

Tekstur tanah yang baik untuk tambak adalah: liat, lempung berliat, lempung liat berdebu, lempung berdebu, lempung, dan lempung liat berpasir (Ilyas et al., 1987). Secara umum, kandungan fraksi liat tanah tambak di Kecamatan Bulakamba tergolong tekstur liat berat atau memiliki kandungan liat yang sangat tinggi. Dikatakan oleh Boyd (1995), bahwa suatu material tanah yang merupakan campuran dari partikel yang berbeda ukuran dan mengandung minimum $30 \%$ liat adalah ideal untuk konstruksi tambak. Kandungan liat tanah ini mendukung usaha budidaya tambak yang masih memerlukan pakan alami seperti klekap sebagai sumber utama makanan bagi organisme yang dibudidayakan di tambak. Dalam hal ini, teknologi tradisional sampai madya adalah pilihan yang dapat dilakukan di tambak.

\section{Kesesuaian dan Pengelolaan Lahan}

Daerah penyangga perlu disediakan dalam mendesain hamparan pertambakan. Daerah penyangga berupa lahan yang berbatasan dengan laut atau sungai yang tidak digunakan untuk budidaya tambak, melainkan untuk tempat tumbuhnya vegetasi mangrove yang merupakan tanaman asli di daerah tersebut. Areal ini perlu disediakan sebagai jalur hijau yang lebarnya minimal 130x nilai rata-rata perbedaan air pasang tertinggi dan terendah tahunan dalam satuan meter yang diukur dari garis surut terendah (Pasal 27 Keppres Nomor 32 tahun 1990 tentang Pengelolaan Kawasan Lindung) dan minimal 100 m dari kiri kanan sungai besar dan $50 \mathrm{~m}$ kiri kanan sungai kecil di luar pemukiman (Pasal 16 Keppres Nomor 32 tahun 1990), yang merupakan sumber air bagi hamparan pertambakan. Jika rata-rata perbedaan air pasang tertinggi dan terendah di Kabupaten Brebes relatif sama dengan Kota Semarang yaitu sekitar 1,0 m; maka lebar jalur hijau di kawasan pesisir Kabupaten Bulakamba adalah $130 \mathrm{~m}$. Hal ini juga sesuai dengan Pasal 6 Peraturan Pemerintah Republik Indonesia Nomor 26 tahun 2008 tentang Rencana Tata Ruang Wilayah Nasional (PP No. 26, 2008) bahwa strategi untuk pencegahan dampak negatif kegiatan manusia yang dapat menimbulkan kerusakan lingkungan hidup yaitu melindungi kemampuan lingkungan hidup untuk menyerap zat, energi dan atau komponen lain yang dibuang ke dalamnya.

Hasil analisis kesesuaian lahan menunjukkan bahwa dari luas tambak yang ada di Kecamatan Bulakamba, yaitu 1.485,3 ha ternyata tidak ada tambak yang tergolong sangat sesuai (kelas S1), 145,7 ha tergolong cukup sesuai (kelas S2), dan 1.339,6 ha tergolong kurang sesuai (kelas S3) (Gambar 2). Hasil analisis kesesuaian lahan tersebut digolongkan kesesuaian lahan aktual sebab dinilai untuk kondisi saat ini berdasarkan data sifat biofisik tanah atau sumberdaya lahan sebelum lahan tersebut diberikan masukanmasukan yang diperlukan untuk mengatasi kendala atau faktor pembatas. Apabila usaha perbaikan dapat dilakukan, kelas kesesuaian lahan dapat naik satu tingkat pada golongan kesesuaian lahan potensial (Ritung et al., 2007).

Budidaya udang dengan teknologi tradisional sampai madya dapat dilakukan pada tambak yang tergolong cukup sesuai. Polikultur udang dan bandeng atau monokultur bandeng dapat dilakukan pada tambak yang tergolong kurang sesuai pada areal yang tanah non-sulfat masam dan polikultur 


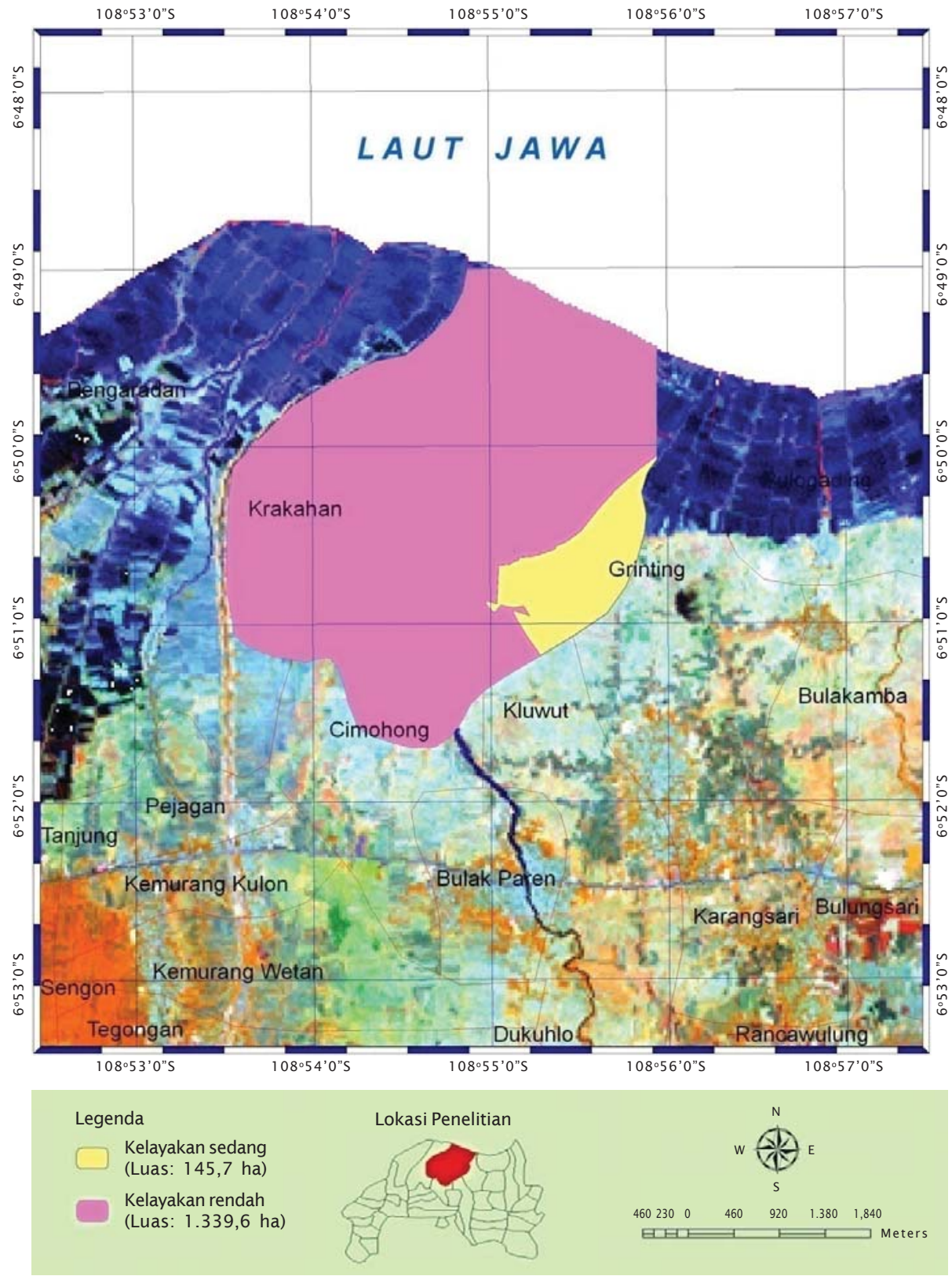

Gambar 2. Peta kesesuaian lahan aktual untuk budidaya tambak pada musim kemarau di Kecamatan Bulakamba Kabupaten Brebes Provinsi Jawa Tengah

Figure 2. Actual ponds suitability map for aquaculture in dry season, Bulakamba Sub-district Brebes District Central Java Province

bandeng dan rumput laut dapat dilakukan pada tambak yang tergolong kurang sesuai pada areal yang memiliki kandungan $\mathrm{S}_{\mathrm{POS}}$ tanah yang tinggi.
Faktor utama pembatas kesesuaian lahan untuk budidaya tambak di Kecamatan Bulakamba adalah kandungan unsur atau senyawa penyebab kemasaman pada areal- 
areal tertentu. Unsur atau senyawa penyebab kemasaman yang dimaksud adalah: pirit, bahan organik, besi, dan aluminium yang akhirnya dicerminkan dengan nilai $\mathrm{S}_{\text {pos }}$ yang relatif tinggi. Pengelolaan lahan terutama tanah yang dapat dilakukan untuk menurunkan potensi kemasaman tanah adalah melalui remediasi baik berupa pengeringan dan pembilasan tanah maupun melalui pengapuran. Prinsip remediasi melalui pengeringan dan pembilasan tanah adalah pengeringan tanah untuk mengoksidasi pirit, perendaman untuk melarutkan dan menetralisir kemasaman atau menurunkan produksi kemasaman lanjut dan pembilasan untuk membuang hasil oksidasi dan meminimumkan cadangan unsur-unsur beracun dalam tanah (Mustafa \& Rachmansyah, 2008).

Pupuk yang mengandung nitrogen seperti urea, menjadi faktor yang penting diperhatikan dalam budidaya tambak di Kecamatan Bulakamba, terutama yang dikelola secara tradisional dan tradisional plus serta madya. Penggunaan pupuk yang mengandung nitrogen seperti urea diharapkan dapat menurunkan rasio $\mathrm{C}: \mathrm{N}$ tanah yang juga dapat mempercepat proses penguraian bahan organik. Namun demikian, dengan tingginya kandungan berbagai bentuk nitrogen dalam air, sehingga upaya pemupukan susulan dengan urea perlu mendapat perhatian.

Kandungan fosfat pada tanah tambak Kecamatan Bulakamba tergolong tinggi (ratarata lebih dari $60 \mathrm{mg} / \mathrm{L}$ ), baik pada kedalaman 0-0,2 m maupun 0,5-0,7 m. Ketersediaan fosfat lebih besar $60 \mathrm{mg} / \mathrm{L}$ dalam tanah tambak dapat digolongkan sebagai slight atau tergolong baik dengan faktor pembatas yang sangat mudah diatasi (Karthik et al., 2005). Oleh karena itu, pemberian pupuk yang mengandung fosfat seperti SP-36 hanya disarankan dilakukan pada tambak-tambak dengan kandungan fosfat tanah kurang dari $60 \mathrm{mg} / \mathrm{L}$.

Pada tanah yang mengandung liat yang tinggi (> 60\%), Boyd (1995) menetapkan konsentrasi bahan organik < 8\% tergolong slight yaitu baik dan faktor pembatasnya mudah diatasi untuk budidaya tambak. Oleh karena itu, pada tambak yang kandungan liatnya lebih besar $60 \%$ dan kandungan bahan organiknya lebih rendah dari $8 \%$ disarankan untuk mengaplikasikan pupuk kandang sebagai sumber bahan organik yang juga dapat memperbaiki struktur tanah yang dapat menyebabkan pertumbuhan makanan alami terutama klekap akan lebih baik.

Salinitas air yang relatif tinggi, sebagai akibat survai yang dilaksanakan pada musim kemarau, juga menjadi salah satu faktor pembatas kesesuaian lahan untuk budidaya tambak di Kecamatan Bulakamba. Oleh karena itu, pemanfaatan sumber air tawar menjadi lebih penting serta usaha pergantian air yang lebih tinggi frekuensinya dapat dilakukan pada areal yang dekat dengan sumber air laut.

\section{KESIMPULAN DAN SARAN}

Peubah kualitas air Sungai Kluwut dan pesisir Kecamatan Bulakamba kurang mendukung sebagai sumber air primer untuk kegiatan budidaya pada musim kemarau. Kualitas tanah tanah tambak secara umum dapat mendukung usaha tambak yang dikelola secara tradisional sampai madya, di mana pada areal tertentu dijumpai adanya potensi kemasaman walaupun dalam jumlah yang rendah. Dari luas tambak yang ada di Kecamatan Bulakamba, yaitu 1.485,3 ha ternyata tidak ada tambak yang tergolong sangat sesuai (kelas S1), 145,7 ha tergolong cukup sesuai (kelas S2); dan 1.339,6 ha tergolong kurang sesuai (kelas S3). Upaya remediasi perlu dilakukan pada areal yang memiliki kandungan $\mathrm{S}_{\mathrm{POS}}$ tanah tinggi dan perlu pula dilakukan pemupukan yang mengandung nitrogen seperti urea untuk menstabilkan rasio C:N tanah serta penambahan pupuk kandang untuk memperbaiki struktur tanah yang didominasi oleh fraksi liat. Perlu adanya upaya input teknologi dan infrastruktur untuk aliran massa air tawar dan penentuan pola dan waktu budidaya dengan memperhatikan faktor kunci salinitas. Perlu pula adanya pemantauan kualitas air pada saat musim hujan untuk mendapatkan skenario lain dari kesesuaian lahan untuk tambak pada musim hujan.

\section{UCAPAN TERIMA KASIH}

Diucapkan terima kasih kepada Sdr./i. Makmur, Mat Fahrur, Sutrisyani, dan Reny Yulianingsih serta Sutrisyani atas bantuannya dalam pengambilan contoh tanah/sedimen dan air di lapangan dan mempersiapkan analisis di laboratorium. Diucapkan terima kasih kepada Bapak Kepala Dinas dan seluruh staf Dinas Kelautan dan Perikanan Kabupaten Brebes atas segala bantuannya selama pelaksanaan penelitian ini. 


\section{DAFTAR ACUAN}

Abdurachman, A., Haryati, U., \& Juarsah, I. 2006. Penetapan kadar air tanah dengan metode gravimetri. Dalam. Kurnia, U., Agus, F., Adimihardja, A., \& Dariah, A. (Eds.) Sifat Fisik Tanah dan Metode Analisisnya. Balai Besar Penelitian dan Pengembangan Sumber Daya Lahan Pertanian. Bogor, hlm. 131-142.

Ahern, C.R. \& Blunden, B. 1998. Designing a soil sampling and analysis program. In. Ahern, C.R., Blunden, B., \& Stone, Y. (Eds.) Acid Sulfate Soils Laboratory Methods Guidelines. Acid Sulfate Soil Management Advisory Committee, Wollongbar, NSW, p. 2.1-2.6.

Ahern, C.R., McElnea, A., \& Baker, D.E. 1998a. Peroxide oxidation combined acidity and sulfate. In. Ahern, C.R., Blunden, B., \& Stone, Y. (Eds.) Acid Sulfate Soils Laboratory Methods Guidelines. Acid Sulfate Soil Management Advisory Committee, Wollongbar, NSW, p. 4.1-4.17.

Ahern, C.R., McElnea, A., \& Baker, D.E. 1998b. Total oxidisable sulfur. In. Ahern, C.R., Blunden, B., \& Stone, Y. (Eds.) Acid Sulfate Soils Laboratory Methods Guidelines. Acid Sulfate Soil Management Advisory Committee, Wollongbar, NSW, p. 5.1-5.7.

Ahern, C.R. \& Rayment, G.E. 1998. Codes for acid sulfate soils analytical methods. In. Ahern, C.R., Blunden, B., \& Stone, Y. (Eds.) Acid Sulfate Soils Laboratory Methods Guidelines. Acid Sulfate Soil Management Advisory Committee, Wollongbar, NSW, p. 3.1-3.5.

Anonymous. 1991. Mariculture of seaweeds. In. Shokita, S., Kakazu, K., Tomori, A., \& Toma, T. (Eds.), Aquaculture in Tropical Areas. Midori Shobo Co., Ltd., Tokyo, p. 31 95.

ANZECC (Australian and New Zealand Environment and Conservation Council). 2000. Australian and New Zealand Guidelines for Fresh and Marine Water Quality. National Water Quality Management Strategy Paper No. 4, Australian and New Zealand Environment and Conservation Council and Agriculture and Resource Management Council of Australia and New Zealand, Canberra.

Association of Southeast Asian Nations (ASEAN). 1978. Manual on Pond Culture of Penaeid Shrimp. ASEAN National Coordinating Agency of the Philippines, Manila, $132 \mathrm{pp}$.

Balai Besar Pengembangan Budidaya Air Payau (BBPBAP). 2007. Penerapan Best manage- ment Practices (BMP) Pada Budidaya Udang Windu Intensif. Ditjen Perikanan Budidaya Departemen Kelautan dan Perikanan, Jakarta, $68 \mathrm{hlm}$.

Boyd, C.E. 1989. Water Quality Management and Aeration in Shrimp Farming. Fisheries and Allied Aquacultures Department Seri No. 2. Alabama Agricultural Experiment Station, Auburn University, Auburn.

Boyd, C.E. 1995. Bottom Soil, Sediment, and Pond Aquaculture. Chapman and Hall, New York, $348 \mathrm{pp}$.

Boyd, C.E. 2008. Pond bottom soil analyses. Global Aquaculture Advocate September/ October, 91-92.

Bray, W.A., Lawrence, A.L., \& Leung-Trujillo, J.R. 1994. The effect of salinity on growth and survival of Penaeus vannamei, with observations on the interaction of IHHN virus and salinity. Aquaculture, 122: 133-146.

Canadian Council of Resource and Environment Ministers. 1987. Canadian Water Quality. Canadian Council of Resource and Environment Ministers, Ontario.

Chanratchakool, P., Turnbull, J.F., Funge-Smith, S., \& Limsuwan, C. 1995. Health Management in Shrimp Ponds. Second edition. Aquatic Animal Health Research Institute, Department of Fisheries, Kasetsart University Campus, Bangkok, 111 pp.

Chen, T.P. 1972. Fertilization and feeding in coastal fish farms in Taiwan. In. Pillay, T.V.R. (Ed.) Coastal Aquaculture in the Indo-Pacific Region. Fishing News (Books) Ltd., London, p. $410-437$.

Effendi, H. 2003. Telaah Kualitas Air bagi Pengelolaan Sumber Daya dan Lingkungan Perairan. Penerbit Kanisius, Yogyakarta, $258 \mathrm{hlm}$.

Food and Agriculture Organization (FAO). 1976. A framework for land evaluation. In. FAO Soil Bulletin 32. Soil Resources Management and Conservation Service and Water Development Division, FAO, Rome.

Haliman, Widodo, R., \& Adijaya, S.D. 2006. Udang vannamei. Penerbit Swadaya, Jakarta.

Hurtado-Ponce, A.Q. \& Umezaki, I. 1987. Growth rate studies of Gracilaria verrucosa (Gigartinales, Rhodophyta). Botanica Marina, 30: 223-226.

Karthik, M., Suri, J., Saharan, N., \& Biradar, R.S. 2005. Brackish Water Aquaculture Site Selection in Palghar Taluk, Thane district of Maharashtra, India, Using the Tech- 
niques of Remote Sensing and Geographical Information System. Aquacultural Engineering, 32: 285-302.

Lazur, A. Tanpa tahun. Growout Pond and Water Quality Management. JIFSAN Good Aquacultural Practies Program.

Liaw, W.K. 1969. Chemical and biological studies of fishponds and reservoirs in Taiwan. Rep. Fish Culture Res., Fish. Series, Chin. Am. Joint Commission on Rural Reconstruction, 7: 1-43.

Liu, C.-I. 1989. Shrimp disease, prevention and treatment. In. Akiyama, D.M. (Ed.) Proceedings of the Southeast Asia Shrimp Farm Management Workshop. American Soybean Association, Singapore, p. 64-74.

McElnea, A.E. \& Ahern, C.R. 2004a. KCl extractable $\mathrm{pH}\left(\mathrm{pH}_{\mathrm{KCC}}\right)$ and titratable actual acidity (TAA). In: Acid Sulfate Soils Laboratory Methods Guidelines. Queensland Department of Natural Resources, Mines and Energy, Indooroopilly, Queensland, Australia, p. B2-1-B2-3.

McElnea, A.E. \& Ahern, C.R. 2004b. Peroxide $\mathrm{pH}\left(\mathrm{pH}_{\mathrm{ox}}\right)$, titartable peroxide acidity (TPA) and excess acid neutralising capacity $\left(\mathrm{ANC}_{\mathrm{E}}\right)$. In. Acid Sulfate Soils Laboratory Methods Guidelines. Queensland Department of Natural Resources, Mines and Energy, Indooroopilly, Queensland, Australia, p. B3-1-B3-7.

McElnea, A.E. \& Ahern, C.R. 2004c. Sulfurperoxide oxidation method. In. Acid Sulfate Soils Laboratory Methods Guidelines. Queensland Department of Natural Resources, Mines and Energy, Indooroopilly, Queensland, Australia, p. B7-1-B7-2.

McElnea, A.E. \& Ahern, C.R. 2004d. Sulfur $1 \mathrm{M} \mathrm{KCl}$ extraction $\left(\mathrm{S}_{\mathrm{KCl}}\right)$. In. Acid Sulfate Soils Laboratory Methods Guidelines. Queensland Department of Natural Resources, Mines and Energy, Indooroopilly, Queensland, Australia, p. B8-1-B8-2.

Melville, M.D. 1993. Soil Laboratory Manual. School of Geography, The University of New South Wales, Sydney, 74 pp.

Menon, R.G. 1973. Soil and Water Analysis: A Laboratory Manual for the Analysis of Soil and Water. Proyek Survey O.K.T. Sumatera Selatan, Palembang, 190 pp.

Moore, J.W. 1991. Inorganic Contaminants of Surface Water. Springer-Verlag, New York. $334 \mathrm{pp}$.

Mustafa, A. \& Rachmansyah. 2008. Kebijakan dalam pemanfaatan tanah sulfat masam untuk budidaya tambak. Dalam. Sudradjat, A., Rusastra, I W., \& Budiharsono, S. (Eds.) Analisis Kebijakan Pembangunan Perikanan Budidaya. Pusat Riset Perikanan Budidaya, Jakarta, hlm. 1-11.

Mustafa, A., Rachmansyah, \& Hanafi, A. 2007a. Kelayakan Lahan untuk Budi Daya Perikanan Pesisir. Dalam: Kumpulan Makalah Bidang Riset Perikanan Budidaya. Disampaikan pada Simposium Kelautan dan Perikanan Tanggal 7 Agustus 2007 di Gedung Bidakara, Jakarta. Pusat Riset Perikanan Budidaya, Jakarta, $28 \mathrm{hlm}$.

Mustafa, A., Rachmansyah, \& Kamariah. 2010. Karakteristik Tanah di bawah Tegakan Jenis Vegetasi Mangrove dan Kedalaman Tanah Berbeda di Kabupaten Mamuju Provinsi Sulawesi Barat. Balai Riset Perikanan Budidaya Air Payau, Maros, $27 \mathrm{hlm}$.

Mustafa, A., Tarunamulia, \& Sammut, J. 2007b. Klasifikasi Kesesuaian Lahan untuk Budidaya Tambak di Indonesia. Balai Riset Perikanan Budidaya Air Payau, Maros, 34 hlm.

Poxton, M. 2003. Water quality. In: Lucas, J.S. \& Southgate, P.C. (Eds.) Aquaculture: Farming Aquatic Animals and Plans. Blackwell Publishing Ltd., Oxford, p. 47-73.

Purwadhi, F.S.H. 1999. Sistem Informasi Geografis. Dalam. Suharmanto, Tjinda, F., Yulmontoro, S., Arisdyo, I.L., Ginting, R., \& Effendi, A. (Eds.) Pengantar Teknologi, Aplikasi Penginderaan Jauh Satelit dan Sistem Informasi Geografi. Lembaga Penerbangan dan Antariksa Nasional dan Badan Pengkajian dan Penerapan Teknologi, Jakarta, hlm. 367-494.

Poernomo, A. 1988. Pembuatan Tambak Udang di Indonesia. Seri Pengembangan No. 7. Balai Penelitian Perikanan Budidaya Pantai, Maros, $30 \mathrm{hlm}$.

Poernomo, A. 1989. Faktor lingkungan dominan pada budidaya udang intensif. Dalam. Bittner, A. (Ed.), Budidaya Air. Yayasan Obor Indonesia, Jakarta, hlm. 66-120.

Ponce-Palatox, J., Martinez-Palacios, C.A., \& Ross, L.G. 1997. The effect of salinity and temperature on the growth and survival rates of juvenile white shrimp, Penaeus vannamei, Boone, 1931. Aquaculture, 157: 107-115.

Ritung, S., Wahyunto, Agus, F., \& Hidayat, H. 2007. Panduan Evaluasi Kesesuaian Lahan dengan Contoh Peta Arahan Penggunaan Lahan Kabupaten Aceh Barat. Balai Pene- 
litian Tanah dan World Agroforestry Centre (ICRAF), Bogor, Indonesia, $39 \mathrm{hlm}$.

Ritvo, G., Shitumbanuma, V., \& Dixon, J.B. 2004. Soil solution sulfide control by two ironoxide minerals in a submerged microcosm. Aquaculture, 239: 217-235.

Sawyer, C.N. \& McCarty, P.L. 1978. Chemistry for Environmental Engineering. Third edition. McGraw-Hill Book Company, Tokyo.

Sulaeman, Suparto, dan Eviati. 2005. Petunjuk Teknis Analisis Kimia Tanah, Tanaman, Air, dan Pupuk. Diedit oleh: Prasetyo, B.H.,
Santoso, D., \& Widowati, L.R. Balai Penelitian Tanah, Bogor, $136 \mathrm{hlm}$.

Swingle, H.S. 1968. Standardization of chemical analysis for waters and pond muds. FAO Fisheries Report, 44(4): 397-406.

Tsai, C.-K. 1989. Water quality management. In. Akiyama, D.M. (Ed.) Proceedings of the Southeast Asia Shrimp Farm Management Workshop. American Soybean Association, Singapore, p. 56-63.

UNESCO/WHO/UNEP. 1992. Water Quality Assessments. In. Chapman, D. (Ed.). Chapman and Hall Ltd., London. 